\title{
INFLUENCE OF TEMPERATURE, INCUBATION TIME, ANTIGEN DENSITY AND AGE OF THE CULTURE IN AGGLUTINABILITY OF LEPTOSPIRES
}

\author{
Núbia Seyffert*; Éverton Fagonde da Silva; Viviane Lorenzato Bermudez; Claudiomar Soares Brod \\ ${ }^{1}$ Centro de Controle de Zoonozes, Faculdade de Medicina Veterinária, Universidade Federal de Pelotas, Pelotas, RS, Brasil.
}

This paper corresponds to an "extended abstract" selected for oral presentation in the $22^{\text {nd }}$ Brazilian Congress of Microbiology, held in Florianópolis, SC, Brazil, in November 17-20, 2003

\begin{abstract}
In leptospirosis, the Microscopic Agglutination Test (MAT) is the basis of serological diagnosis and the most widely used. In our study, the MAT was applied to evaluate the influence of temperature, incubation time, antigen density and age of the culture in the agglutinability of Leptospires and the interference of these factors in diagnosis. Three serum samples with titers of 100,800 and 25.600 to the serovar tande (local isolate) of canicola serogroup were used with different combinations among the four factors. There was a significant relation among all factors, specially between the antigen density and age of the culture.
\end{abstract}

Key words: Leptospira, microscopic agglutination, Leptospirosis, laboratorial diagnosis.

\section{INTRODUCTION}

Leptospirosis is an economically important zoonosis occurring worldwide in animals and humans (5). There is no sensitive, specific, low-cost, rapid and widely available diagnostic test for leptospirosis. Since 1926, a variety of tests has been developed for sorodiagnosis of Leptospirosis $(2,4,7)$. The MAT is the serological procedure most often used for the diagnosis of leptospirosis, but it is difficult to standardize (6). The MAT is the "gold standard" procedure for detecting leptospiral antibodies according to the Brazilian Ministry of Health.

\section{MATERIALS AND METHODS}

In our experiment, 3 serum samples with MAT titers of 100 , 800 and 25600 against tande serovar were used. The antigen used had three different ages: 3,10 and 28 days old and three different densities: $2 \times 10^{8}, 4 \times 10^{8}$ and $6 \times 10^{7}$ leptospiral organisms $/ \mathrm{mL}$, determined in a Petroff Hausser chamber. The sera were diluted in phosphate-buffered saline $\mathrm{pH}$ 7.2, starting at 1:12.5, and mixed with an equal volume of antigen (6). The mixtures were incubated at $4{ }^{\circ} \mathrm{C}, 30^{\circ} \mathrm{C}$ and $37^{\circ} \mathrm{C}$ and the agglutination was read after 15, 30, 60, 120, 180, 240, 300, 360 and 1440 minutes, by dark-field microscopy. The reported titer was the reciprocal of the highest dilution that agglutinated at least $50 \%$ of the leptospires, when compared to the buffer control (6).

\section{RESULTS}

After 594 readings the reactions with highest precocity followed in Figs. 1, 2 and 3.

All sera achieved $100 \%$ agglutination in 60 min. The sera with the highest titers required longer incubation time, regardless their age, density and temperature. At $37^{\circ} \mathrm{C}$, there was desagglutination after 1440 minutes. At $4^{\circ} \mathrm{C}$ there was net agglutination since the first minutes of the reaction.

\section{DISCUSSION}

Many papers report comparative studies of factors that interfere in MAT. In 1926, Schuffner and Mochtar (3) described

*Corresponding author. Mailing address: Centro de Controle de Zoonoses, Faculdade de Medicina Veterinária, Universidade Federal de Pelotas. Campus Universitário, s/nº, Caixa Postal 354. 96010-900, Pelotas, RS, Brasil. E-mail: nbsey@bol.com.br 


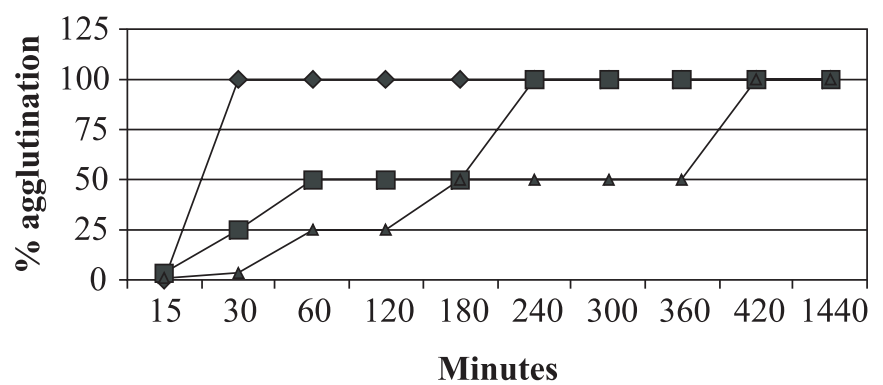

Figure 1. Percentage of agglutination of three sera (titers 100; 800 and 25600 ) incubated at $4^{\circ} \mathrm{C}$, using three days old leptospires and density of $6 \times 10^{7}$ leptospires $/ \mathrm{mL}$.

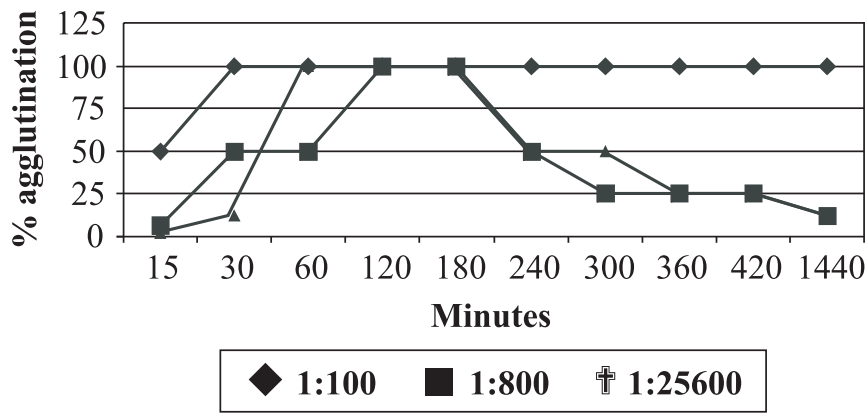

Figure 2. Percentage of agglutination of three sera (titers 100; 800 and 25600 ) incubated at $30^{\circ} \mathrm{C}$, using three days old leptospires and density of $2 \times 10^{8}$ leptospires $/ \mathrm{mL}$.

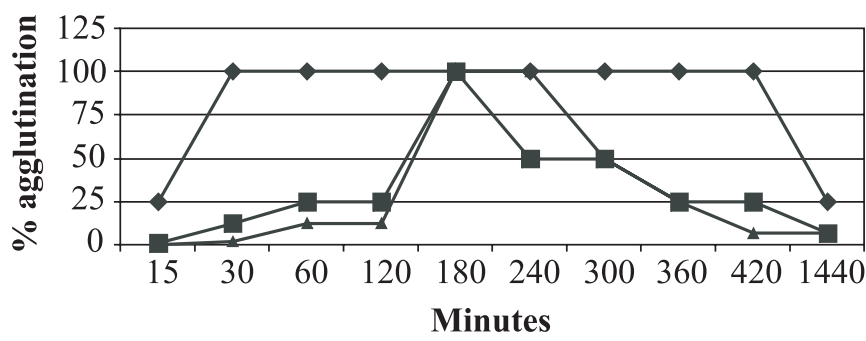

Figure 3. Percentage of agglutination of three sera (titers 100; 800 and 25600 ) incubated at $37^{\circ} \mathrm{C}$, using ten days old leptospires and density of $4 \times 10^{8}$ leptospires $/ \mathrm{mL}$.

the phenomenon of agglutination in human and animal sera, when the reaction was read at 16-20 hours. Since then, the method was improved by other authors $(1,3,9)$, who evaluated the influence of incubation time, incubation temperature, reading of the end-point titer and age of the culture. Four to 14 days old cultures, incubated at $30-32^{\circ} \mathrm{C}$ and containing $1-2 \times 10^{8}$ leptospiral organisms $/ \mathrm{mL}$ are recommended for the test (6). In this study, it was observed that the serum with low titer (100) could be read from a 30 minutes of incubation, but the sera with higher titers required longer than the recommended time to achieve their end-point titer. The 3 days old antigen achieved a better performance than the other antigens. The recommended density showed the best performance. Incubation at $4^{\circ} \mathrm{C}$ is important when the reading cannot be done within the recommend deadline. For a quick screening, in laboratories with intensive routine, the reading can be done with relative confidence from 60 minutes. The age and density of the antigen are important variables which may affect the results.

\section{RESUMO}

\section{Influência da temperatura, tempo de incubação, densidade do antígeno e idade da cultura na aglutinabilidade das leptospiras}

$\mathrm{Na}$ leptospirose, o teste de soroaglutinação microscópica (MAT) é a base do diagnóstico sorológico, sendo amplamente usado. Em nosso estudo, o MAT foi aplicado para avaliar a influência da temperatura, tempo de incubação, densidade do antígeno, a idade da cultura na aglutinabilidade das leptospiras e a interferência desses fatores na interpretação do diagnóstico. Três amostras de soro com títulos de 100, 800 e 25600 para o sorovar tande (isolado local), do sorogrupo canicola foram utilizadas com combinações diferentes entre os quatro fatores. Houve uma significante relação entre todos os fatores principalmente a densidade do antígeno e a idade da cultura.

Palavras-chave: Leptospira, soroaglutinação microscópica, Leptospirose, diagnóstico laboratorial

\section{REFERENCES}

1. Borg-Petersen, C.; Fagroeus, A. The influence of the antigen density and other factors on the serum titer in the agglutination-lysis test for leptospirosis. Acta. Path., 26:4, 1949.

2. Bragger, J.M.; Adler, B. A card test for the serodiagnosis of human leptospirosis. J. Clin. Pathol., 29(3):198-202, 1976.

3. Cole, J.R.; Sulzer C.R.; Pursell, A.R. Improved micro technique for the leptospiral agglutination test. Appl. Microbiol., 25(6):976-980, 1973.

4. Effler, P.V.; Bogard, A.K.; Domen, H.Y.; Katz, A.R.; Higa, H.Y.; Sasaki, D.M. Evaluation of eight rapid screening tests for acute leptospirosis in Hawaii. J. Clin. Microbiol., 1464-1469, 2002.

5. Ellis, W.A. Leptospirosis. J. Small Anim. Pract., 27:683-692, 1986.

6. Faine, S. Guidelines for the Control of leptospirosis. Geneva. World Health Organization. 1982. 171p. (Who offset publications, 67).

7. Merien, F.; Amouriaux, P.; Perolat, P.; Baranton, G.; Saint Girons, I. Polymerase chain reaction for detection of Leptospira spp. in clinical samples. J. Clin. Microbiol., 30:2219-2224, 1994.

8. Myers, D.M. Effect of culture medium on the agglutinability of leptospires by the microscopic agglutination test. Rev. Asoc. Arg. Microbiol., 8(1):14-20, 1976.

9. Wolff, J.W.; Broom, J.C. The Genus Leptospira Noguchi, 1917, Problems of classification and a suggested system based on antigenic analysis. Doc. Med. Geog. Trop., 6:78-95, 1954. 